\title{
Ssciendo
}

Ethics \& Bioethics (in Central Europe), 2021, 11 (1-2), 1-13

DOI:10.2478/ebce-2021-0007

\section{Good life and good death in the Socratic literature of the fourth century BCE}

\author{
Vladislav Suvák ${ }^{1}$
}

\begin{abstract}
The paper outlines several forms of ethical attitude to good life and good death in the Socratic literature of the fourth century BCE. A model for the Socratic discussions could be found in Herodotus' story about the meeting between Croesus and Solon. Within their conversation, Solon shows the king of Lydia that death is a place from which the life of each man can be seen as the completed whole. In his Phaedo, Plato depicts Socrates' last day before his death in a similar spirit, as the completion of his beautiful life. However, there is no consensus regarding opinions on death among the Socratics. The final part of the paper outlines various meanings of death in the writings of the first generation of the Socratic authors, which arise from different attitudes that the individual philosophers hold regarding the soul as well as other topics. This part puts the principal emphasis on Aristippus, who is considered as the most controversial figure of the Socratic movement. Aristippus makes an interesting opposite to Plato concerning death, since he associates the philosopher's endeavour for a good life solely with that which is here and now.
\end{abstract}

Keywords: death, soul, Solon, Socrates, Plato, Aristippus

\section{A Prologue to Plato: Solon}

One of the most famous passages of Herodotus' Histories tells the story of the meeting between Croesus and Solon (I.29-33). ${ }^{2}$ Croesus was the well-known king of Lydia, who conquered almost all Greek cities in the west of Anatolia. Tribute from the subdued cities and the proceeds of gold mines made Croesus the richest sovereign of Anatolia. At the time, the flourishing Sardis was visited by many foreigners, including Solon, who established the laws of Athens (I.29). Croesus welcomed Solon as his guest in the palace and hosted him for three days; on the fourth day, Croesus commanded his servants to display the king's wealth. At a convenient moment, he asked the Athenian, who was renowned for his "love of wisdom", whether he has ever met the happiest man (ỏ $\lambda \hat{\imath} \omega \dot{\tau} \alpha \tau \sigma \zeta) .{ }^{3}$ Herodotus immediately explains to his readers that Croesus asked the question intentionally, since he considered himself as the happiest man. But contrary to the king's expectations, Solon did not begin to flatter Croesus and spoke the truth: "Yes, my lord: Tellus of Athens". Croesus was surprised at his answer and wanted to know why Tellus is the happiest man. Solon explained that Tellus lived in a time of prosperity, that he had beautiful and good sons, lived to see his grandsons and at the end passed away by a glorious death during the defence of Athens (I.30). ${ }^{4}$

Solon's narration about Tellus' happiness aroused Croesus' curiosity. He hoped that he could be at least the second happiest man, but Solon continued by naming other happy men, Cleobis and Biton of Argos. ${ }^{5}$ After they performed a heroic deed, they got into Hera's good graces, and she enabled them to die in their sleep on the floor of her temple (I.31). Then Croesus got angry

\footnotetext{
${ }^{1}$ University of Prešov (Slovakia); vladislav.suvak@unipo.sk; ORCID https://orcid.org/0000-0003-3067-9870.

${ }^{2}$ See also Diod. Sic. 9.26. Both of these figures, Croesus and Solon, are historical. They were well-known personalities among the ancient Greeks - Croesus as the last king of Lydia, and Solon as a lawmaker and one of the seven sages of archaic Greece. Before Herodotus, Croesus was mentioned by the lyrical poets Pindar and Bacchylides.

${ }^{3}$ By the way, this is historically the oldest text where the word "philosophize" appears, I.30,11: ...ஸ் $\varphi 1 \lambda \circ \sigma o \varphi \varepsilon ́ \omega v$

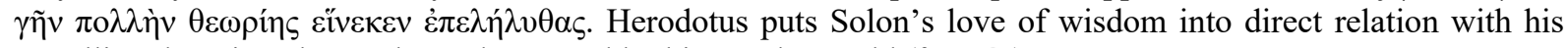
travelling, learning about other cultures and looking at the world ( $\theta \varepsilon \omega \rho i ́ \alpha)$.

${ }^{4}$ It seems that the name Tellus (Té $\left.\lambda \lambda \mathrm{o}\right)$ is not used by accident in this story. It is almost identical with the word $\tau \varepsilon ́ \lambda \circ \varsigma$ ("end", "purpose", in later philosophy "the very completion of life"), which refers to the verb $\tau \varepsilon \lambda \varepsilon v \tau \alpha \tilde{\nu}$ ("come to an end", "complete"; cf. Her. I.30.21; I.31.15).

${ }^{5}$ No more details are known about these two (Lloyd, 1987).
} 
and asked Solon whether he thinks that happiness is worthless. Solon attempted to explain his judgements: He considers the age of seventy years old to be the final boundary of human life and adds that of all those 26,250 days, no two days are the same; all human things are just a conglomeration of chance. ${ }^{6}$ - "Now, I can see that you are extremely rich and that you rule over large numbers of people, but I won't be in a position to say what you're asking me to say about you until I find out that you died well. You see, someone with vast wealth is no better off than someone who lives from day to day, unless good fortune attends him and sees to it that, when he dies, he dies well and with all his advantages intact. After all, plenty of extremely wealthy people are unfortunate, while plenty of people with moderate means are lucky". ${ }^{7}$ If one lives honourably and does not experience any misery, if he is healthy and has good sons, if he is personable, and in addition to this, he ends his life well, then he deserves to be called happy. "But until he is dead, you had better refrain from calling him happy and just call him fortunate". A human being is never completely self-sufficient; although one has something, he lacks something else. One who ends his life having almost everything, and then even he undergoes a pleasant death, is worthy of that designation. Solon completed his speech by words: "It is necessary to consider the end of anything, however, and to see how it will turn out, because the god often offers prosperity to men but then destroys them utterly and completely" (I.32).

Up to now, we have followed Herodotus' narration almost literally. Onwards we will continue in abbreviated form. Croesus said goodbye to Solon - he thought that Solon is an immense ignoramus ( $\dot{\alpha} \mu \alpha \theta \dot{\varepsilon} \alpha ;$ I.33,3) if he does not care about the present good. ${ }^{8}$ However, the following events proved that he was wrong. Divine anger $(\theta \varepsilon \circ \tilde{v}$ vé $\mu \varepsilon \sigma \iota \zeta ;$ I.34,1) descended on the king - Herodotus adds his own judgement and step by step uncovers Croesus' pride and arrogance (v $\beta \rho 1 \varsigma) .{ }^{9}$ Herodotus continues the story and describes how Croesus lost his most beloved son by the hand of a Phrygian he had received into his house. He then follows with a story about Croesus' campaign against the Persians, which he set out on based on the prophecy he was given by the Delphic oracle. Croesus misinterpreted the prophecy, and as a result, his entire empire fell into the hands of the Persian king Cyrus. When Croesus, defeated, was standing on the pyre, Solon's statement that no one who is still alive is happy came to his mind (as it was uttered by some god behind him; бòv $\theta \varepsilon \tilde{\omega} ;$ I.86,15) cf. (Pelling, 2006, pp. 157-158). Only at the moment of his death did Croesus understand that Solon's words do not relate just to him, but to all the people, and particularly to those who consider themselves to be happy (I.86). Croesus admitted his arrogance, and by doing so, he unknowingly displayed wisdom. ${ }^{10}$ Like a distant echo of Solon's words about the happiest man Tellus, who lived in the time of peace and was thus able to raise his sons well, Croesus says to Cyrus: "After all, no one is stupid enough to prefer war to peace; in peace sons bury their fathers and in war fathers bury their sons". Even the Persian king Cyrus then understood that no human things are steadfast.

The historical dating of Solon's journey to Sardis is disputable, because if it had to have happened, as Herodotus states (I.29), during the ten years of travels that Solon took right after he released the Athenian laws (594 BCE), then Croesus was only a little boy at the time. As we know, Croesus assumed his reign around 560 BCE, when Solon was either dead or at least too

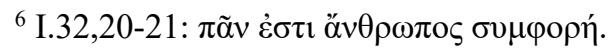

${ }^{7}$ For Herodotus' Histories I use the translation by R. Waterfield.

${ }^{8}$ The term $\dot{\alpha} \mu \alpha \theta \dot{\varepsilon} \alpha(\mathrm{I} .33,3)$ is the direct opposite of the previous designation of Solon's "love of wisdom" (I.30,11). By using this term Herodotus indicates in advance Croesus' arrogant behaviour in the subsequent narration.

9 S. Saïd thinks that Herodotus' narration was influenced by Greek drama, e.g. with regard to a dramatic composition of the whole scene, or the role of prophecy in Sophocles' Oedipus Rex etc. (Saïd, 2002, pp. 134-135).

${ }^{10}$ Note that Solon and Croesus became a common literary theme in the $4^{\text {th }}$ century BCE; cf. e.g. Pseudo-Plato, Epist. 2.311a, where Solon and Croesus are described as sages, and Cyrus as an emperor endowed with power. Later ancient authors also connected Croesus with the seven sages (cf. e.g. Diod. Sic. 9.26).
} 
old to travel. ${ }^{11}$ Thus, there is no suggestion that the conversation between Croesus and Solon actually happened as recorded by our historian. ${ }^{12}$

Herodotus' story sounds almost like a fairy tale. It is a story about the king who did not know happiness, despite being surrounded by enormous wealth. However, the whole story is also interesting due to something else: the significance which Solon attributes to death. Regardless of whether the description of Solon is based on some historical source, its value lies in showing that archaic wisdom considered death to be the criterion of judging a happy life. ${ }^{13}$ In this context, death is neither the "end" nor "evil" (these would be in accord with popular notions of death), but the "completion" - the place, time and point that give sense to a life.

Herodotus makes of Solon Croesus' teacher, but Croesus understood that too late, only when he experienced the changeability of fate in his own skin: First, he loses his son, and then his whole empire. It seems that Herodotus is not only telling a story about Solon, who wants to teach a lesson to Croesus, but that he equally wants to give a lesson to his readers. ${ }^{14}$ Solon is

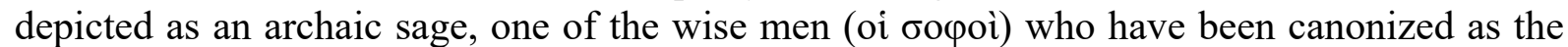
symbolical seven by later tradition. ${ }^{15}$ The meeting between Croesus and Solon is a story about the clash between power and wisdom. Solon does not pose as a teacher; he only answers questions, but his answers nevertheless reveal Croesus' ignorance.

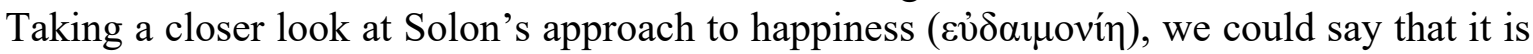
made up of a tranquilly and well-lived life as a whole (Tellus lived to a great age, lived in prosperity, raised good sons etc.). But Cleobis and Biton died young, so a heroic and famous death is a more important criterion of happiness than length of life. ${ }^{16}$ Furthermore, we have to take into consideration the way of life, since Tellus, Cleobis and also Biton were either excellent athletes or brave soldiers. In his speech, Solon presents several models of a good life which put into contrast the luxurious life of the eastern kings with the simple life of the Greeks: ${ }^{17}$ Happiness can be based on self-sufficiency and respectability; life may be happy without suffering, when one is healthy and has virtuously raised sons. But the most important criterion of judging the measure of happiness is death as the culmination of life. ${ }^{18}$ However, this does not mean that death is better than life. ${ }^{19}$ Death is a place from which we can see the life of each person as the completed whole. What matters the most is how one completes his life. For Solon, to die well means to die after living a full-valued life in the presence of family or the closest friends, to die in a way that will be respectfully remembered by the following generations.

\footnotetext{
${ }^{11}$ This issue was pointed out already in antiquity. Plutarch (Solon 27.1) writes that many authors argued for the time implausibility of Solon's journey to Sardis, but in his opinion, it is not right to reject a story which is "so famous and so well attested". Contemporary historiography calls Herodotus' story into question (cf. e.g. Wallace, 1983, pp. 86-95; Busine, 2002, pp. 18-20, etc.).

${ }^{12}$ One of the possibilities of how to explain the time discrepancy is based on the assumption that Solon met Croesus' father, King Alyattes.

${ }^{13}$ The opinions on happiness, death and length of life that Herodotus attributes to Solon correspond with the information found in Solon's lyric poetry; cf. (Noussia-Fantuzzi, 2010, pp. 14-17).

${ }^{14}$ In the foreword to his Histories, Herodotus writes that the purpose of this work is "to preserve the fame of the important and remarkable achievements". Note that Herodotus has similar thoughts as Solon, e.g. on Fortune, that it is unstable and changeable (I.5,3-4), or that divinity is envious; therefore, it is good for a one to be lucky in one thing and unsuccessful in another (III.40) etc. The reason why Herodotus put the story about Solon and Croesus at the beginning of the Book I of the Histories may also be that he intended to introduce his own opinions on life and happiness, which he develops in the following books; cf. (Shapiro, 1996, p. 348), with references to further authors.

${ }^{15} \mathrm{Cf}$. Diog. Laert. I 40. Although Herodotus is one the oldest sources of the archaic wisdom tradition, it seems that he does not know the phrase "seven sages" yet; cf. (Busine, 2002, p. 17).

${ }^{16}$ Solon names Cleobis and Biton in the second place probably because they, in contrast to Tellus, died young.

${ }^{17}$ R. V. Munson suggests that Solon's account, as well as the terminology used, is unclear (Munson, 2001, p. 184).

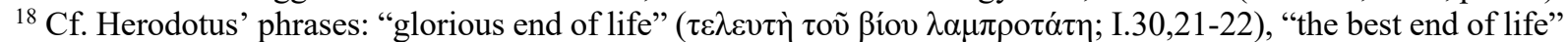

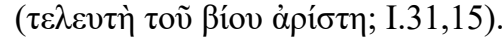

${ }^{19}$ M. Lloyd argues for such an interpretation (Lloyd, 1987).
} 


\section{The last day of Plato's Socrates}

Recalling the dramatic circumstances of Socrates' death, we can ask questions that are similar to those of Solon: Was Socrates' life happy? Did Socrates die in a way that was a confirmation of his life? We could search for the answers to these questions in several of Plato's dialogues; however, one of them posits almost the same questions as we do - as if Plato had Herodotus' story about Solon and Croesus in his mind when he was writing the dialogue.

The dialogue Phaedo is set on the last day of Socrates' life. Socrates is in prison and awaiting execution - according to the law, when a jailor brings a cup of hemlock, Socrates has to take it and drink it on his own. One would expect the philosopher to be full of anxiety due to what he is awaiting. But to the surprise of all the disciples present, Socrates spent his last day the same way as all other days - he led conversations with his companions. Despite the fact that he was awaiting death, he did not change his way of life. Right at the beginning of the discussion,

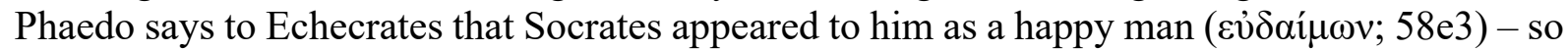
fearlessly and nobly was he dying - and he recollects the strange feeling of a mixture of sorrow and pleasure $(59 \mathrm{~b} 4)$ that overwhelmed him and the others. Plato's portrayal of Socrates as a new type of hero emerges here again: similarly as at the beginning of Charmides, in the concluding passages of Symposium, or in Apology, Socrates is not very eager to talk about his war heroism (Charm. 153a1-153a3); however, he zealously examines himself as well as his intimates through conversations (Apol. 38a5), which he leads regardless of fatigue or danger (Symp. 223d). ${ }^{20}$

The framework of the dialogue is outlined by the opening of Socrates' speech on death and immortality $(63 \mathrm{e}-69 \mathrm{e})$ in the Orphic-Pythagorean fashion $(62 \mathrm{~b}){ }^{21}$ The topic of the speech is a philosopher's care of death ( $\mu \varepsilon \lambda \varepsilon \dot{\tau} \tau \eta$ $\theta \alpha v \alpha$ qov; 81a1-2): Socrates is not afraid of death, even

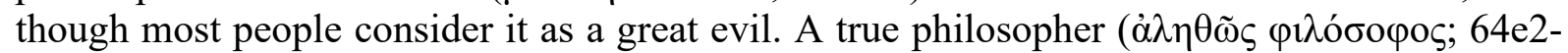

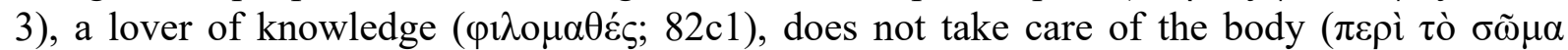
$\theta \varepsilon \rho \alpha \pi \varepsilon i ́ \alpha \varsigma ; 64 \mathrm{~d} 8$ ), does not care for desires, fears, loves, illusions, trivialities, wars and dissensions - on the contrary, he focuses on the soul, because only the soul itself can achieve

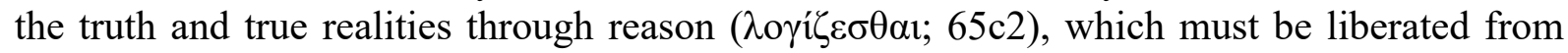

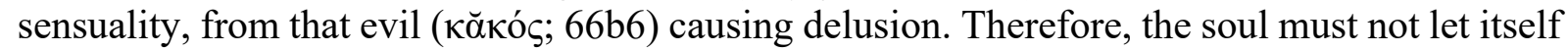
be led by the sense of hearing or sight, or by pain or pleasure. True realities (such as justice, beauty, the good) are not physical. If we want to acquire knowledge, we have to look at the things themselves with the soul itself, and that can be done only after death - during our life, we can do this only partially, provided that we don't let ourselves become infected with the nature of the body (67a5).

Socrates' philosophical programme is clear: he has to purify his soul from the body as much as possible $(67 \mathrm{a}-\mathrm{b})$, since only those who are pure ( $\kappa \alpha \theta \alpha \rho \circ)$ ) will acquire knowledge of all the

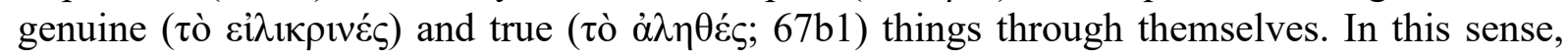
Socrates' care for death is a kind of completion of the philosophical care to which he exhorts the Athenians in Plato's Apology 29d: during life, they should not take care of money, reputation and honour, but rather reason, truth and the soul to be as best as possible. ${ }^{22}$ In Phaedo,

\footnotetext{
${ }^{20}$ In the final chapter of his Memorabilia (Mem. IV 8.2-3), Xenophon describes Socrates' death in a similar way as Plato's Phaedo does: Even in prison, Socrates did not change his way of living - he maintained his cheerfulness

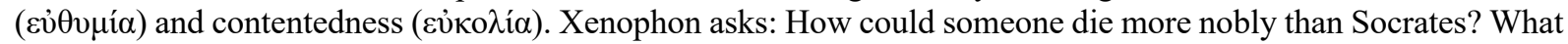

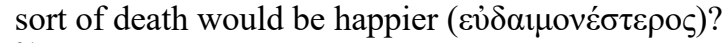

${ }^{21}$ Socrates speech has a similar function as the myth of the True Earth at the end of the dialogue (107c-115a), i.e. that it is not associated with argumentation but refers to belief and conviction; cf. the phrase $\mu \tilde{v} \theta 0 v \lambda \varepsilon_{\gamma} \varepsilon 1 v \kappa \alpha \lambda$ óv (110b1).

${ }^{22}$ Socrates' speech on death and immortality (Phd. 63e-69e) is, in a certain way, the completion of his defence at the Athenian court $(63 \mathrm{~b} 2,69 \mathrm{~d} 7)$.
} 
Socrates mentions the hope that after death he will acquire what he has strived for all of his life (67b10).

Socrates' subsequent conversation with Cebes and Simmias is similar to the educational lessons known from Plato's other dialogues. The course of the dialogue is a depiction of an education pursued in two phases: ${ }^{23}$ In the first phase (69e-88c), Socrates and his companions are engaged in a discussion consisting of three attempts to justify the immortality of the soul. From the viewpoint of misologia (89d), ${ }^{24}$ it is shown that no logoi, i.e. neither Socrates' nor the others', are sufficiently justified. ${ }^{25}$ The second phase (91c-115a) consists of several (distinctively Platonic) reflections which have a (distinctively Socratic) therapeutic character in relation to logoi: ${ }^{26}$ At first, we are witnesses to Socrates refutation of Simmias' suggestion that we define the soul as a harmony (91d-95e). Afterwards, Socrates contemplates for a while, and he continues with recalling why he had diverged from the examination of nature and substituted it with the "second sailing" towards the Forms (95e-102a): the true cause of things is not visible; therefore, we have to get into the field of logos and come to know that beautiful things are beautiful by their beauty, just things are just by justice, etc. ${ }^{27}$ Subsequently, a fourth attempt to argue for the immortality of the soul, based on the causes of arising (102b-107b), is made. ${ }^{28}$ Finally, those present listen to the eschatological myth about the True Earth, which ought to support the philosophical belief that the care of the soul in this (physical) life will be rewarded with a better (spiritual) life after death (107c-115a). The myth about the Earth could be approached as the completion of Plato's therapy, which is related to Socrates' introductory speech on the attitude of a philosopher to death, and to the following discussion about the immortality of the soul as well. The collective character of the reflections constituting the second phase is emphasized in the passage 90e4-91a1, where Socrates exhorts the others to strive for the healthy condition of their logoi - "you and the others for the sake of your whole life still to come, and I for the sake of death itself". 29

\footnotetext{
${ }^{23}$ Ronna Burger shows that Plato has intentionally divided the dialogue Phaedo into two parts, which are separated by the passage about misologia precisely in the middle of the dialogue: in her view, these two parts point to the tension between concern about oneself (the fear of death, the hope for immortality) and concern about logoi (the fear of misologia, the art of reasonable argumentation) (Burger, 1984, pp. 1-13).

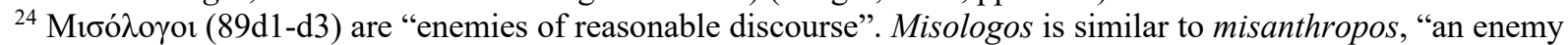
of men", a person who has come to the conviction that there is nothing sound in anyone at all. One can fall into misanthropy the same way that one can fall into misology. Misology itself is probably an allusion to antilogies (cf. Phd. 90c1, Phd. 91a), or contradictory arguments. Following on from Protagoras, antilogies were developed by the Sophists of the time and also by some of Plato's rivals among the Socratics, e.g. Antisthenes (see fragments SSR V A 152 and SSR V A 153).

${ }^{25}$ Let me mention that if we link misology with a "desire for victory" ( $\varphi$ iлovıкí $\alpha$ ), which is the opposite of a "desire

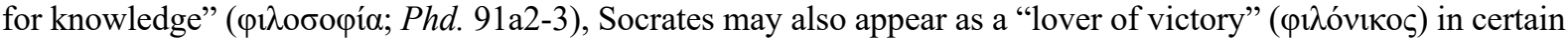
situations, which he self-ironically admits in the passage 89c3-4, where he says that he will cut his hair and will not grow it back until he gains victory over Simmias' and Cebes' opinions. Socrates aims to emphasize that the meaning of a dialectical conversation is not to win, but to save or cure logoi (cf. 90e4-91a1). More important than Socrates' opinion is the truth, the care of the truth (91b-c).

${ }^{26} \mathrm{~J}$. Crooks points out the therapeutic character of the second half of the dialogue (Crooks, 1998, pp. 117-125). Support for such an interpretation can be found in the passage 89a, where Phaedo admits to Echecrates how delighted he was during the whole conversation: Socrates was not only nimble but also kind to his young interlocutors. And he immediately noted (89a5): “... how sharply he was aware of the effect, the discussion had on us, and then how well he healed our distress..." (translated by G. M. A. Grube). In this passage we could also look for an answer to the question, what does the sacrifice for Asclepius, which Socrates exhorts all those present to with his last words (Phd. 118a7-8), relate to?

${ }^{27}$ Socrates emphasizes that he, in fact, talks about this "second sailing" from the very beginning of the discussion (cf. Phd. 65d).

${ }^{28}$ The interlocutors do not have any other objections to Socrates' fourth argument for the immortality of the soul - Cebes is fully convinced, and Simmias still has some small doubts, but he is unable to express them.

${ }^{29}$ Grube's translation. As J. A. Arieti notes, the central topic of Phaedo is not the immortality of the soul, but the courage with which Socrates approaches his death (Arieti, 1991, p. 220).
} 
From the viewpoint of the overall composition of the dialogue, we could say that the most important task to which Plato's Socrates exhorts his disciples, and, in fact, us, the readers of the dialogue, too, is the care of the self and of others. Such care is pursued in dialectical conversation, which helps us to purify the soul from unhealthy, false opinions. ${ }^{30}$ Care of the self is at the same time the care of others, since in the course of the dialogue Socrates purifies himself equally as his intimates, whose souls he helps to purify, as well. In Plato's Phaedo, the

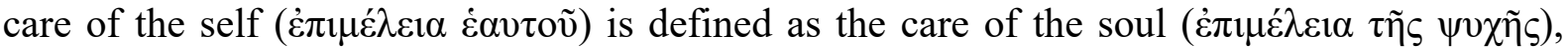
which is ultimately the care of the truth ( $\dot{\alpha} \lambda \dot{\eta} \theta \varepsilon ı \alpha ; 91 b-c)$. If the soul is actually immortal, we must not neglect it - it requires our constant attention, not only for the time of our life but for all time (107c). If the soul wants to be saved from evil, it has to become as best and reasonable as possible - this is the fundamental task of education.

If we place Herodotus' and Plato's text next to each other, we see that Socrates' and Solon's attitudes to death are similar in many respects. It seems that Plato depicts Socrates with regard to a paradigmatic example of the archaic approach to death, i.e. as a contemporary hero who lived out a beautiful life, and the confirmation of that is his beautiful death. All of that may be learnt by reading the final scene of Phaedo, which describes Socrates' dignified dying. A reader

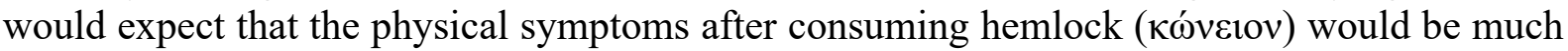
more drastic: disjointed breathing, loss of balance, stomach cramps, vomiting, numbness of the limbs, loss of consciousness, etc. However, in Plato's interpretation, Socrates dies smoothly and tranquilly, ${ }^{31}$ since he would like to show that Socrates' dying is a fulfilment of the central thought of the dialogue, which is the demand for gradual purification of the soul from the body (Phd. 67b-c). The course of the dialogue clearly indicates that Socrates pursues this demand practically, the only one among the others to do so. Plato's depiction of Socrates' dying may be perceived as an amplification of Alcibiades' praise of Socrates' ability to control his body with his mind, even in the tensest life situations (Symp. 220a-220d). ${ }^{32}$

Socrates not only lives but also dies as a happy man who has acted in accordance with virtue for all his life, and therefore he is not afraid of dying (58e 3 ; 63e-64a etc.). Care of others is emphasized by Socrates' interest in his intimates, whom he exhorts to the fulfilment of the philosophical way of life they together decided for and to remain faithful to it, despite the opinion of the majority of Athenians, who sentenced Socrates to death (115b5-c1). For his companions, Socrates becomes an example - only the way a philosopher dies may confirm his way of life.

\footnotetext{
${ }^{30} \mathrm{Cf}$. 115e5-6: "to express oneself badly is not only faulty as far as the language goes, but does some harm to the soul" (Grube's translation).

${ }^{31}$ R. Gautier proposed the radical thesis that Socrates did not know what he was talking about because he was delirious after the consumption of hemlock (Gautier, 1955, pp. 274-275). However, his opinion is groundless from the pharmacological viewpoint - Plato's depiction of Socrates' final moments could be regarded as relatively realistic; cf. (Bloch, 2001, pp. 255-278); (Arihan \& Karaoz Arihan \& Touwaide, 2014, p. 79).

${ }^{32}$ Such a possibility is pointed out by C. Gill, who compares two ancient descriptions of physical symptoms after the consumption of hemlock, Plato's and Nicander's ( $2^{\text {nd }}$ century BCE), and finds considerable differences between them (Gill, 2001, pp. 25-28); cf. also (Ober, 1977). E. Bloch objects to Gill's opinion, when, following from modern and also ancient reports (Theophrastus, Pliny, Pedanius Dioscorides), he distinguishes between various species of hemlock with diverse effects and shows that Plato's description corresponds with Conium maculatum L., which starts to work slowly (Bloch, 2001). However, even if we accept Bloch's explanation, we have to admit that literary adaptation gives each "historical" event a specific meaning - even more so in the case of such a master, as Plato definitely is.
} 


\section{The soul and death in the discussions of the Socratics}

In the course of centuries, the scene of the dying Socrates in Plato's Phaedo has acquired a dominant status among other portrayals of the Athenian sage. ${ }^{33}$ Subsequent generations of philosophers saw Socrates as a prototype of a man whose attitude to death confirms that the soul must not let itself be led by the senses, pain, or pleasure, since we cannot judge justice, beauty and the good on the grounds of physical experience - the fundamental task of a philosopher is to purify his soul from the body (Phd. 67a-b).

When we think about Socrates' historical legacy from the contemporary perspective, we let ourselves be led specifically by that Platonic portrayal. We tend to forget that the Socratics of the first generation created various alternative portrayals of the Master and that they were giving reasons for several attitudes which they considered to be Socratic. Such a circumstance may be caused by the fact that the Socratic writers competed against each other over which portrayal would assert itself, which, in turn, would draw attention to its creator, and he could then claim himself as the true successor of the Master. Therefore, we should not be surprised when we discover among the attitudes with the label "Socratic" even those that do not correspond with Phaedo.

From this perspective, there is an interesting passage in Plato's Apology (40c-41c) that outlines two ways we could approach to death. Socrates does not work with the Orphic or Pythagorean notions here, like he does in Phaedo, but he refers to stories that are comprehensible for most Athenians: Death is either a non-being and thus a dead one does not have any feelings, or it is some kind of a transition (relocation) from this place to another one. Socrates explains that if death was similar to a night of sleep with no dreams, he would benefit from that (the whole of time would become a single night). The second option is an allusion to the Homeric religion. ${ }^{34}$ However, at the same time we can see that Socrates does not describe Hades as a dark opposite of the divine Olympus, but he likens it to joyous life in Elysium. Socrates uses the story to call the present judges into question (from the beginning of the dialogue, he calls them "citizens of Athens") - only when we get to Hades' realm will we meet with the true judges, who have already proved their justness. ${ }^{35}$ If death meant a possibility to have a conversation with Orpheus or Homer, Socrates would not hesitate to die even several times (his words indicate a strong irony but also a lightness of thought on death). All those famous men in Hades are immortal and happier than men here on Earth.

One of the most discussed topics among the first generation Socratics was undoubtedly self-

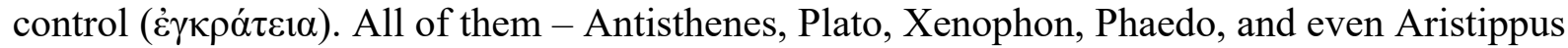
- in some measure exhorted to the strengthening of self-control. Two questions were discussed in particular: 1) What is that which is able to control? 2) What is that which should be controlled? (cf. Boys-Stone \& Rowe, 2013, p. 124). Both questions arise from the experience (already present in Greek drama) of such a man who cannot control his anger, jealousy or erotic passion, but, on the other hand, he also has the will to stand against the things which enslave him. The metaphor of slave and sovereign is not accidental, since it epitomizes an individual's feelings on the threshold of the classical period: one who wants to be truly free has to become

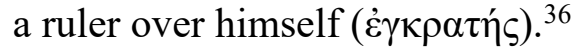

\footnotetext{
${ }^{33}$ This is found not only in literature but also in the fine arts. On behalf of all the works, let me at least mention the Neoclassical painting La Mort de Socrate (1787) by Jacques-Louis David, which today belongs to the collections of the Metropolitan Museum of Art in New York.

${ }^{34}$ Cf. Apol. 41c: "if indeed what we are told is true" (translated by G. M. A. Grube).

${ }^{35}$ Socrates immediately amplifies this motive when he talks about the meeting with Palamedes and Ajax, whose death was the result of an unjust conviction.

${ }^{36} \mathrm{Cf}$. Aristippus fragment quoted below: Plutarch., De liber. educ. 7 p. 4 F [= SSR IV A 5]. Antisthenes thematizes

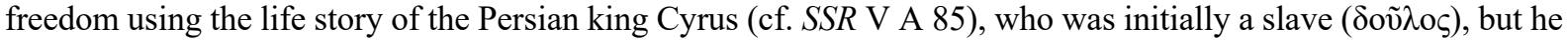
was not afraid to carry out laborious deeds ( $\pi$ óvor), and he was able to use them to the benefit of good goals. Thanks to this, he earned his freedom ( $\dot{\varepsilon} \lambda \varepsilon v \theta \varepsilon \rho i ́ \alpha)$ and became an ideal ruler ( $\beta \alpha \sigma \imath \lambda \varepsilon v ́ \varsigma)$. Slavery means not only
} 
It is worth noticing that Plato's Phaedo substitutes the "political model" used by Antisthenes, Aeschines or Xenophon, for the "medical model": The soul must not become infected with the nature of the body; the soul has to purify itself, i.e. to get rid of the body to avoid infection with evil. Socrates' answer to both questions in Plato's Phaedo could be as follows: Only the soul is able to rule the body, since, in relation to the body, the soul is like a "head" that uses the body as its "tool" 37 - and everything that has a physical nature must be controlled, because pain and pleasure lead us to false notions about the good, beauty and justice. From such answers, it follows that loving somebody means loving his soul. ${ }^{38}$ Somewhere around this time the idea came into existence of a radical ontological opposite between the soul ( $\psi v \chi \eta \dot{)})$ and the body $(\sigma \tilde{\omega} \mu \alpha)$, which endured in Western thought in various forms up to the twentieth century. ${ }^{39}$

Almost all Socratics answer the first question in the same spirit as Plato: The soul, or more precisely its rational ability, represents an active principle that leads one from a life dependent on pleasant feelings to a life based on the right decision-making. Reasonableness enables one to live in such a way that he benefits from his life not only momentarily (while a pleasant feeling lasts) but permanently. And we should not forget that the Socratics saw life as a whole; therefore, they argued that life may be described as "good" or "bad" only at the moment of death.

The answers to the second question are not as clear as those to the first one. Since if we think that one should subdue pleasures in the first place, then we have to admit that not all pleasures have a physical character. Some of them may concern the soul - for example, when we are pleased from the conversation with a friend, or when we experience an uplifting feeling while thinking about a beloved person. Mature Plato solves this issue by teaching about the parts of the soul, which include the irrational parts, as well - the highest purpose of education is to achieve the ability to control the irrational parts of the soul by one's reason ( $\tau$ ò $\lambda \sigma \gamma 1 \sigma \mu$ ó $).{ }^{40}$

Some Socratics concede that not only the soul may influence the body (thus it may transform the body), but that this is also applicable in reverse. The notion of mutual influencing between the soul and the body is connected with physiognomonics. ${ }^{41}$ It seems that it was no accident that this term occurred for the first time in the Socratic movement, since several Socratics put the famous ugliness of their Master into contrast with his beautiful soul. ${ }^{42}$ The comparisons of Socrates to a statue of Silenus or the satyr Marsyas in Plato's Symposium (215b) may be classified among those which problematize the notions of a direct relationship between the state of one's soul and his physical appearance.

Besides the indirect criticism of the physiognomonic art (Plato, Xenophon), the opposite tendencies can be found among the Socratics, as well. Aristippus, for example, says that the soul may display its ugliness outwardly; after all, even a "woman applies cosmetics to her face, but shows an unshapely soul". ${ }^{43}$ On the ground of this fragment, it seems that Aristippus -

social status but also dependence on physical passions, which every free man has to get under his control (cf. the example of Alcibiades in SSR V A 141). The numbering of the fragments of the Socratics relies on Giannantoni's edition of ancient testimonies: Socratis et Socraticorum Reliquiae; (Giannantoni, 1990) abbreviation SSR.

37 Cf. Pseudo-Plat. Alcib. I. 129c-130c.

${ }^{38}$ Cf. Plat., Symp. 210a-e.

${ }^{39}$ Note that for Homer $\psi v \chi \eta$ still means "life" that is leaving a man in the moment of death (cf. Il. 23.100). The turn regarding the understanding of $\psi v \chi \eta$ (= "one's character", "cognitive ability", "soul” as an active principle) arrived with the Orphic-Pythagorean background, and the first indications of such an approach can be found in Heraclitus.

${ }^{40}$ Cf. Plat., Resp. 435c-441d; Phdr. 246a-256b.

${ }^{41}$ The art of physiognomony in antiquity is discussed in detail in (Zelinová \& Kalaš, 2021; in Slovak).

${ }^{42}$ For Socrates' appearance, see Xenoph., Symp. II.18-19; V.5-7; IV.19); Plat., Symp. 215b, 216d; Plat., Theaet. $143 \mathrm{e}$.

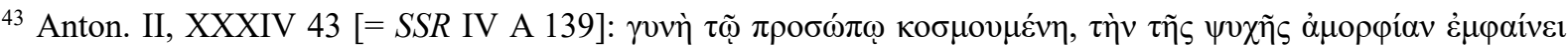
(translated by G. R. Boys-Stone \& C. J. Rowe). 
similarly to Antisthenes - admits a close relationship between one's character and his physical appearance. Antisthenes comments on this in a similar way, when he, in an allusion to Homer, says that "souls have the appearance of the bodies that surround them". ${ }^{44}$ Antisthenes wrote a separate work about physiognomonic art titled On the Sophists, where he apparently ironized the activities of the Sophists: they inculcate young men with their wisdom in the same way that shop retailers feed their piglets by force. ${ }^{45}$

Within a discussion concerning the physiognomonic art, an important role is played by Zopyrus, who appears in Phaedo's dialogue of the same name: The Persian magician Zopyrus reveals Socrates' character behind his appearance (a bull-neck, robust nape, bulging eyes), which indicates a stupid and desirous man who is controlled by his physical passions. Socrates' companions are horrified by the magician's judgement and stand up for Socrates, but he surprisingly admits that he, in fact, has natural tendencies towards physical passionateness. $\mathrm{He}$ is able to strengthen his self-control only thanks to philosophy. ${ }^{46}$

The Socratic authors attribute various meanings to death not only in relation to their understanding of the soul but also regarding the issues they consider to be key. For some of them (Antisthenes, Plato), ${ }^{47}$ the soul has an immortal nature - if we identify it with reason, then we can arrive at the knowledge that it is taking part in the reasonable governance of the whole kosmos (Xenophon, Plato). ${ }^{48}$ Others consider death as something that endangers both the soul and the body. One anecdote shows how Aristippus got scared when he found himself in danger of his life: Once he was sailing to Corinth when he got caught by a strong storm and became frightened. Someone told him: "We laymen are not afraid, but you philosophers act like cowards". Aristippus replied: "That is because of the different types of soul we are fighting for!" 49 On the grounds of this story, we could assume that death poses a threat to the body as well as to the soul. Unlike Socrates as depicted in Plato's dialogues (Apology, Phaedo, Crito), who is not afraid of death, Aristippus does not hide his fear, perhaps because he does not believe in the immortality of the soul. At the same time, we can see that distinguishing between uneducated and educated souls is important for Aristippus. The key to his Socratism could lie just in this distinction: only a philosophical education can cultivate a man - only thanks to education of the soul can one achieve happiness. ${ }^{50}$ If we go even further in our reading of this anecdote, we could say that each soul is different depending on education: Aristippus knows (in contrast to the laymen) the value of his soul, i.e. the value of his education. As one report

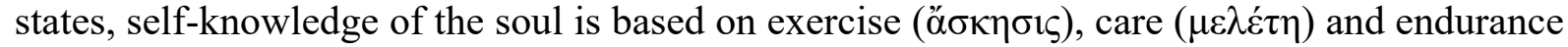

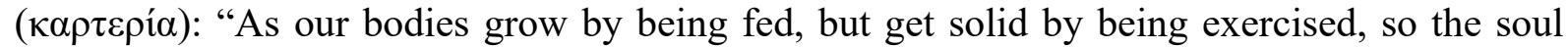

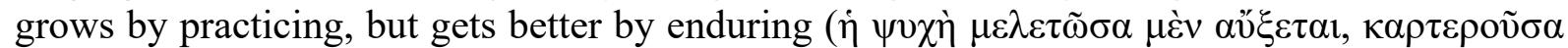

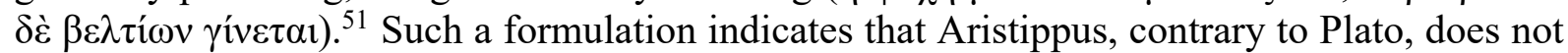
consider theoretical knowledge to be superior to everything else. The key terms here are the verbs $\mu \varepsilon \lambda \varepsilon \dot{\tau} \eta \nu$ and $\kappa \alpha \rho \tau \varepsilon \rho \varepsilon \tilde{v}$; the former expresses the requirement of taking care of our souls, the latter even more vehemently says that we must endure in this care for our whole life. There is an obvious similarity between Aristippus and Antisthenes, two Socratics whom doxographers put into sharp contrast. Even Antisthenes considers endurance ( $\alpha \rho \tau \varepsilon \rho i ́ \alpha)$ as one of the most

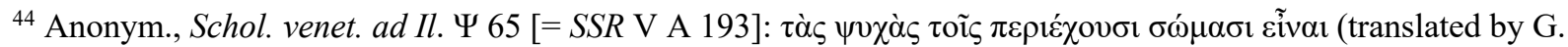
R. Boys-Stone \& C. J. Rowe).

${ }^{45} \mathrm{Cf}$. Athen. XIV $656 \mathrm{~F}$ [= SSR V A 62].

${ }^{46}$ Cf. SSR III A 1 - III A 18.

${ }^{47}$ Cf. Antisthenes in Diog. Laert. VI 5 [= SSR V A 176]: "Those who wished to be immortal must, he maintained, live piously and justly" (translated by Pamela Mensch). Cf. also Gnom. Vat. 743 n. 5 [=SSR V A 32].

${ }^{48}$ Socrates lectures Aristodemus in this spirit in Xenoph., Mem. 1.4.17-18; cf. Plat., Phil. 30d-e.

${ }^{49}$ Diog. Laert. II 71 [= SSR IV A 49] (translated by G. R. Boys-Stone \& C. J. Rowe).

${ }^{50}$ Cf. Diog. Laert. II 70 [= SSR IV A 125]: "He said it was better to be a beggar than to be uneducated ( $\left.\dot{\alpha} \pi \alpha i ́ \delta \varepsilon v \tau o v\right)$; for the former is in need of money, the latter of humanity ( $\alpha v \theta \rho \omega \pi \imath \sigma \mu о \tilde{v} \delta \varepsilon \dot{\varepsilon} \nu \tau \alpha \iota)$ " (translated by Pamela Mensch).

${ }^{51}$ Gnom. Vat. 743 n. 34 [= SSR IV A 124] (translated by G. R. Boys-Stone \& C. J. Rowe).
} 
important excellences or virtues. ${ }^{52}$ This could mean that the Socratic authors have much in common even despite the various differences between them. A practical understanding of selfcontrol, self-sufficiency and endurance, which means virtues based on exercise or training

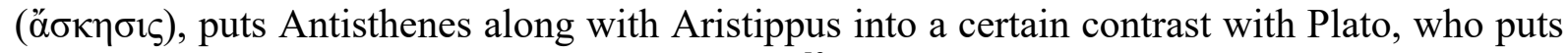

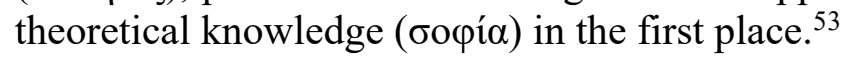

Some critics suggest that the hedonism attributed to Aristippus represents an attitude that excludes him from the Socratic circle. But how would they explain that several ancient authors consider Aristippus to be Socrates' follower and the founder of one of the most influential Socratic schools? ${ }^{54}$ The hesitation in evaluating Aristippus follows from the fact that we cannot give a definite answer to the question of whether he holds an attitude of ethical hedonism, according to which pleasure is the only good. ${ }^{55}$ Since the ancient testimonies are not unanimous regarding this question, we have to consider carefully how we will read them. ${ }^{56}$

Above all, we should critically approach those reports which depict Aristippus as a copybook example of a hedonist, because they take the form of polemic or have even a hostile tone. ${ }^{57} \mathrm{An}$ alternative view on Aristippus could show that he was an integral part of the Socratic movement, even though he was thinking in a more extravagant and provocative way than his comrades ${ }^{58}$ Despite undeniable hedonistic tendencies, it is obvious that Aristippus shares basic convictions with the other Socratics, for example, a belief in the irreplaceable role of philosophical education for the achievement of happiness. ${ }^{59}$ There is one anecdote that historians link with Aristippus' attitude to excellence ( $\dot{\alpha} \rho \varepsilon \tau \eta$ ), which could serve as an appropriate example of the importance that he attributes to philosophical education: "It is said that, when, on some occasion, during drinking, Dionysius commanded each of his guests to dance dressed in purple, Plato refused saying 'I could not wear a woman's clothes', whereas Aristippus accepted and, as he was about to dance, made the comment that 'even in a Bacchic dance the temperate woman ( Aristippus paraphrase a verse from Euripides' Bacchae (836 and 317), which we could attribute to their good education. However, that should not be seen as the only message of the anecdote. If we approach it from a certain distance, we will see that it is connected with self-control (one of the meanings of the term $\sigma \tilde{\omega} \varphi \rho o v)$ in a much larger extent than, as Sextus thinks, with

\footnotetext{
${ }^{52}$ Cf. Xenoph., Mem. I 2,19 [= SSR V A 103]. Xenophon's understanding of the excellences (virtues), among

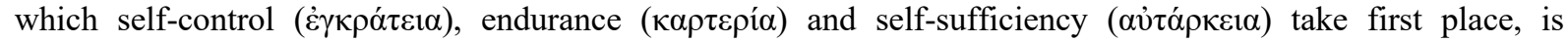
presumably influenced by Antisthenes; cf. Xenoph., Mem. I 2,1-2; I 2,19-24.

${ }_{53}$ Cf. Aristotle's report in his Rhetoric 1398b29-32 [= SSR IV A 16].

${ }^{54}$ Cf. Apul., Flor. 2 [= SSR IV A 104]: Diog. Laert. II 68 [= SSR IV A 104]: When asked what he had gained from philosophy, he said, "To be able to consort confidently with everyone" (translated by Pamela Mensch).

${ }^{55}$ Several reports testify against ethical hedonism; cf. e.g. Stob. III 17, 7 [= SSR IV A 98]: "The person who masters pleasure is not the one who abstains from it, but the one who uses it without being manipulated by it; similarly, the person who masters a ship or a horse is not the one who does not use it, but the one who steers it wherever he

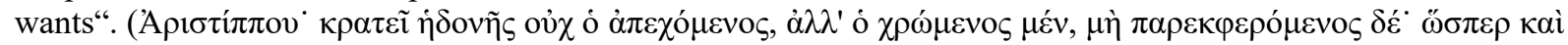

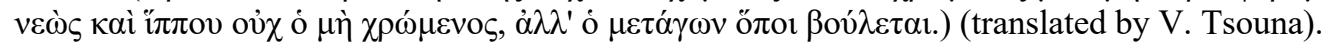

${ }^{56} \mathrm{~A}$ fundamental issue arises from the fact that the later ancient authors do not distinguish the attitudes of Aristippus the Socratic from the teachings of his grandson Aristippus the Younger, who in all probability laid foundations of the later Hellenistic school; cf. Diog. Laert. II 86-87 (problematization of pleasures on the grounds of the teaching about passions of the soul).

${ }^{57}$ Several testimonies speak against the black-and-white attitude to Aristippus' hedonism; cf. e.g. Cic., De orat. III 16, 61: the most pleasant thing for Aristippus was to lead conversations about pleasure with Socrates.

${ }^{58}$ Hedonistic attitudes are also attributed to Socrates by Plato (Prot. 351a-356c), Xenophon (Mem. II 1, 27-34; IV 5,$9 ;$ IV 8, 6) or Phaedo in his dialogue Zopyrus. For the Socratic background of Aristippus' hedonism, see (Lampe, 2015, pp. 31-35); (Tsouna, 2021, pp. 389-403).

${ }^{59}$ The same conviction is defended by Socrates in Plato's Apology. Aristippus' courage to tell the truth under all circumstances could be seen as the typical Socratic attribute; cf. Gnom. Vat. 743 n. 43 [= SSR IV A 108]; cf. also testimonies in SSR IV A 104.

${ }^{60}$ Diog. Laert. II 78 [= SSR IV A 31] (translated by V. Tsouna).
} 
Aristippus' indifference to the way of dressing or with the Socratic-Platonic conviction that excellence once achieved cannot be lost. ${ }^{61}$ Perfect self-control ( $\left.\sigma \omega \varphi \rho о \sigma v ́ v \eta\right)$ in the ethical as well as political sense is the ripest fruit of philosophical education. ${ }^{62}$

Moreover, even the story about how Aristippus became Socrates' follower is similar to many other Socratic chreiai: Aristippus got enthused about the examination of Socrates, his words and his philosophy, the aim of which was to bring each one to the awareness of the faults in his action and to get rid of them. Aristippus came to Athens right after Ischomachus gave him a few examples of Socrates' dialectic investigation ( $\delta 1 \alpha \lambda \varepsilon \gamma o ́ \mu \varepsilon v o \varsigma)$, and he was so intensely moved that he suffered a physical collapse. ${ }^{63}$ In this context, to recognize one's faults means to try to know oneself ( $\dot{\varepsilon} \pi \gamma \nu \tilde{\omega} v \alpha \imath$ ) - but self-knowledge should be understood as an activity, not as a state ${ }^{64}$ It is just this activity that makes Aristippus the Socratic - together with the effort to give his self-knowledge - a distinctive character with respect to the problematization of the pleasure. ${ }^{65}$

Aristippus (contrary to Plato or Euclides) belongs to the radical Socratics who reject the examination of nature or theoretical-logical reflections and focus their attention exclusively on ethical questions. ${ }^{66}$ Several testimonies indicate that Aristippus attributes to the good an ethical as well as an aesthetical value (the terms $\alpha \gamma \alpha \theta$ óv and $\kappa \alpha \lambda$ óv are synonymous in Greek). ${ }^{67}$ The anecdotes about Aristippus' affection towards the beautiful hetaira Lais could serve as indirect evidence for that - these anecdotes can be even labelled as typically Socratic topoi, since they thematise the nature of the soul through the physical display of beauty. ${ }^{68}$ Several stories say that Aristippus loved Lais of Corinth, but he was not jealous when other men fell in love with her. ${ }^{69}$ This could mean, on the one hand, that Aristippus did not hold a possessive relationship toward her, and, on the other hand, that he managed to control his delight from the pleasures that intercourse with the famous courtesan had brought to him. ${ }^{70}$ Aristippus' well-known words that he may have had her, but he is not had by her, should not be considered to be a display of his superiority to the beautiful hetaira but as the manifestation of his self-control, since he explains that Lais possesses the other men but she does not possess him. ${ }^{71}$

On the grounds of ancient reports, we can conclude that Aristippus puts the benefit from achieved knowledge above knowledge about many things ( $\pi \circ \lambda v \mu \alpha \dot{\theta} \theta \varepsilon 1 \alpha)$ - this usefulness alone makes of us virtuously acting men $(\sigma \pi \mathrm{ov \delta \alpha i \tau ol}) .{ }^{72}$ Also, the distinction between a conventional

\footnotetext{
${ }^{61}$ Sext. Emp., Pyrr. hypot. I 14, 155 [= SSR IV A 32].

${ }^{62}$ The opposite of $\sigma \omega \varphi \rho о \sigma u ́ v \eta$ is $\mu \alpha v i ́ \alpha$, "madness", which is often caused by passions or uncontrollable desires.

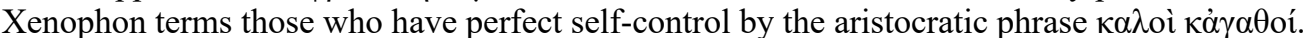

${ }^{63}$ Plut., De curios. 2 [= SSR IV A 2]. Plutarch's choice of words depicting Aristippus' state after he heard about Socrates would be appropriate rather to someone who fell in love and suffers from unrequited love: $\gamma \varepsilon v \varepsilon \dot{\sigma} \sigma \theta \alpha$

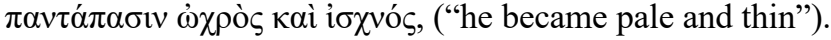

${ }^{64}$ It seems that Aristippus has adopted from Socrates several features of his dialectic examination; cf. Xenoph., Mem. III 8, 1-7 [= SSR IV A 165]; Plutarch,. De prof. in virt. 9 p. 80 B-C [= SSR IV A 111]; Xenoph., Mem. II 1, 1-17 [= SSR IV A 163]; Phlod., De rhet. fr. 12 col. XLI 7 sqq [= SSR IV A 11]; Diog. Laert. II 71.

${ }^{65}$ For details, see (Tsouna, 2015, pp. 1-25).

${ }^{66}$ Cf. Aristot., Metaph. 996a32-996b1 [= SSR IV A 170]. According to Aristotle, Aristippus dismisses mathematics because it is not concerned with the good and evil.

${ }^{67}$ Cf. Aristot., Metaph. 1078a31-34 [= SSR IV A 171]. Here Aristotle probably argues against Aristippus.

${ }^{68}$ Cf. e.g. Plato's dialogues Charmides (on Socrates' affection toward Charmides), or Symposion (on Alcibiades' love for Socrates), or Aeschines' dialogue Alcibiades (on Socrates' education of Alcibiades).

${ }^{69}$ Lais of Corinth or of Hyccara (Gr. $\Lambda \alpha i \xi$ ) was a prisoner of war, later known as the famous Athenian hetaira, who was said to be the most beautiful woman on earth. Her name is linked with the fortunes of several distinguished personalities (Demosthenes, Diogenes). Aristippus dedicated one of his dialogues to her. For the interpretation of Aristippus' anecdotes concerning his relationship to Lais, see (Tsouna, 2020, pp. 400-401).

${ }^{70}$ Cf. Athen. XIII 588 E-F [= SSR IV A 92]; Plutarch., Amat. 4 p. 750 D-E [= SSR IV A 93].

${ }^{71}$ Cicer., Ad famil. IX 26, 2 [= SSR IV A 95]: Habeo, non habeor a Laide; Lactant., Divin. instit. III 15, 15 [= SSR IV A 95].

${ }^{72}$ Diog. Laert. II 71 [= SSR IV A 122].
} 
and philosophical education is influenced by the Socratic spirit: "He [Aristippus] used to say that those who obtained a general education but were deprived of philosophy were like the suitors of Penelope; for they had their way with Melantho, Polydora and the other serving women and were able to do everything but marry the mistress herself" ${ }^{73}$ What people without a philosophical education lack is the ability of care of the self, care of the soul, the awareness of one's own nature and the work on its improvement. ${ }^{74}$ Care of the soul enables us to make the right decisions in every matter of life, and primarily in our choice of pleasures. We cannot achieve happiness without care of the soul, without the ability of right decision-making. Aristippus is Socratic just because of this conviction and not due to an affirmative or negative answer to the question of whether the soul is immortal. If Aristippus showed a fear of death when his life was in danger, as the anecdote from Diogenes Laertius reports, maybe it was because he considers death as the end of the philosophical endeavour for a good life. ${ }^{75}$ After death, - if there is any "after death" - a philosophical education loses its own value. This value is primarily tied to life. Aristippus does not want to attach to death such meanings that would heroize the completed life of a philosopher. Philosophical life has to be focused on the present world, not on wandering in lost eras or on waiting for a vague future. ${ }^{76}$ For Aristippus, the philosophical life is, first of all, the way of right decision-making here and now, and so the way to freedom. ${ }^{77}$

The fact that Aristippus attributes different meanings than Plato to death does not mean that he is a minor Socratic. According to Aristippus, the endeavour for a good life ends with death; however, that does not make our efforts useless. In this sense, Aristippus belongs to those Socratics who are focused on the present life, the present world, and not on a promise of a just life after death.

\section{Acknowledgment}

This paper is a part of the research project VEGA 1/0094/20, Aristippus and the Socratic movement. I would like to thank Lívia Flachbartová for her help with the English translation of the text.

\section{References}

ARIETI, J. A. (1991): Interpreting Plato: The dialogues as drama. Savage, MD: Rowman and Littlefield.

ARIHAN, O., KARAOZ ARIHAN, S. \& TOUWAIDE, A. (2014): The case against Socrates and his execution. In: P. Wexler (ed.): History of Toxicology and Environmental Health, vol. 1. Amsterdam: Academic Press, pp. 69-82.

BLOCH, E. (2001): Hemlock Poisoning and the death of Socrates: Did Plato tell the truth? In: T. C. Brickhouse \& N. D. Smith (eds.): The trial and execution of Socrates: Sources and controversies. New York: Oxford University Press, pp. 255-278.

\footnotetext{
${ }^{73}$ Diog. Laert. II 79-80 [= SSR IV A 107] (translated by Pamela Mensch). Several anecdotes depict how Aristippus was making fun of uneducated people; cf. Diog. Laert. II 73 [= SSR IV A 120]: When asked one day how the wise man differs from the unwise, he said, "Send both of them naked among strangers, and you will learn" (translated by Pamela Mensch); Plutarch., De liber. educ. 7 p. 4 F [= SSR IV A 5]: When asked by someone how much the education of his son will cost, he answered, a thousand drachmas. When that man lamented that it is too much and that he would buy a slave for that money, Aristippus replied: "Well then, you will have two slaves, both your son and the one you buy".

${ }^{74}$ Philosophers know their needs thanks to self-knowledge; cf. Diog. Laert. II 69 [= SSR IV A 106].

${ }^{75}$ When asked what his benefit from philosophy is, Aristippus answered that he achieved the ability to talk with anyone without a fear (

${ }^{76}$ Cf. Athen. XII 544 A-B [= SSR IV A 174].

77 Aristippus wished for freedom, i.e. life without commitments to the city; happiness for him means to live anywhere as a stranger; cf. Xenoph., Mem. 2.1.1-4 a 7-17 [= SSR IV A 163].
} 
BOYS-STONE, G. R. \& ROWE, C. J. (2013): The Circle of Socrates: Readings in the FirstGeneration Socratics. Indianapolis: Hackett.

BURGER, R. (1984): The Phaedo: A Platonic labyrinth. New Haven: Yale University Press. BUSINE, A. (2002): Les sept sages de la Grèce antique: Transmission et utilisation d'un patrimoine légendaire d'Hérodote à Plutarque, Paris: De Boccard.

CROOKS, J. (1998): Socrates' last words: Another look at an ancient riddle. In: The Classical Quarterly, 48(1), pp. 117-125.

DIOGENES LAERTIUS (2018): Lives of the eminent philosophers, ed. J. Miller \& trans. P. Mensch. Oxford: Oxford University Press.

GAUTIER, R. (1955): Les dernières paroles de Socrate. In: Revue Universitaire, 64(1), pp. 274-275.

GIANNANTONI, G. (ed.) (1990): Socratis et Socraticorum Reliquiae, vol. I-IV. Napoli: Bibliopolis.

GILL, C. (2001): The death of Socrates. In: T. C. Brickhouse \& N. D. Smith (eds.): The trial and execution of Socrates: Sources and controversies. New York: Oxford University Press, pp. $25-28$.

LAMPE, K. (2015): The birth of hedonism: The Cyrenaic philosophers and pleasure as a way of life. Princeton: Princeton University Press.

LLOYD, M. (1987): Cleobis and Biton (Herodotus 1.31). In: Hermes, 115(1), pp. 22-28.

MUNSON, R. V. (2001): Telling wonders: Ethnographic and political discourse in the work of Herodotus. Ann Arbor, MI: University of Michigan Press.

NOUSSIA-FANTUZZI, M. (2010): Solon the Athenian: The poetic fragments. Leiden: Brill.

OBER, W. (1977): Did Socrates die of Hemlock poisoning? In: New York State Journal of Medicine, 77(1), pp. 254-258.

PELLING, C. B. R. (2006): Educating Croesus: Talking and learning in Herodotus' Lydian Logos. In: Classical Antiquity, 25(1), pp. 141-177.

SAÏD, S. (2002): Herodotus and tragedy. In: E. J. Bakker, I. J. F. de Jong \& H. van Wees (eds.): Brill's companion to Herodotus. Leiden: Brill, pp. 117-145.

SHAPIRO, S. O. (1996): Herodotus and Solon. In: Classical Antiquity, 15(2), pp. 348-364.

TSOUNA, V. (2015): Plato's representation of the 'Socratics'. In: U. Zilioli (ed.): From the Socratics to the Socratic schools: Classical ethics, metaphysics, and epistemology. New York: Routledge, pp. 1-25.

TSOUNA, V. (2020): Aristippus of Cyrene. In: D. C. Wolfsdorf (ed.): Early Greek ethics. Oxford: Oxford University Press, pp. 380-411.

WALLACE, R. W. (1983): The date of Solon's reforms. In: American Journal of Ancient History, 8(1), pp. 86-95.

ZELINOVÁ, Z. \& KALAŠ, A. (2021): Fyziognómonika - zabudnuté antické umenie (pramene a interpretácie) [Physiognomonics - forgotten ancient art (sources and interpretations)]. Bratislava: Univerzita Komenského. 